\title{
WORKSHOP PENDIDIKAN LITERASI MEDIA TENTANG HOAKS DI ORMAS ISLAM PEREMPUAN AISYIYAH
}

\author{
Sri Herwindya Baskara Wijaya ${ }^{1}$, Pawito $^{2}$, Firdastin Ruthnia Yudiningrum ${ }^{3}$, \\ Eka Nada Shofa Alkhajar ${ }^{4}$, Aryanto Budhy Sulihyantoro ${ }^{5}$ \\ ${ }^{1}$ Sekolah Vokasi Universitas Sebelas Maret Surakarta \\ ${ }^{2}$ Fakultas Ilmu Sosial dan Ilmu Politik Universitas Sebelas Maret Surakarta \\ ${ }^{3}$ Sekolah Vokasi Universitas Sebelas Maret Surakarta \\ ${ }^{4}$ Fakultas Ilmu Sosial dan Ilmu Politik Universitas Sebelas Maret Surakarta \\ ${ }^{5}$ Sekolah Vokasi Universitas Sebelas Maret Surakarta \\ sriherwindya@staff.uns.ac.id,pawito_palimin@staff.uns.ac.id, firdastin_ry@staff.uns.ac.id, \\ ekanadashofa@staff.uns.ac.id, aryanto.budhy@yahoo.com
}

\begin{abstract}
Abstrak
Di Indonesia, dari waktu ke waktu mengalami peningkatan jumlah persebaran hoaks (hoax). Faktor utama terjadinya fenomena itu adalah adanya kesenjangan antara teknis penggunaan teknologi media sosial dengan etika penggunaanya. Kegiatan pengabdian kepada masyarakat ini berupa workshop penyuluhan mengenai pendidikan melek internet terutama dengan materi berupa edukasi tentang fenomena hoaks di kalangan mitra kegiatan yakni Pimpinan Ranting Aisyiyah (PRA) Klaseman, Gatak, Sukoharjo. Diharapkan mitra kegiatan bisa lebih memahami tentang pentingnya pendidikan melek internet sehingga dapat berhati-hati dan bijaksana dalam mengakses internet, khususnya media sosial. Kegiatan pengabdian tersebut dilaksanakan pada Sabtu, 22 Agustus 2020, di Desa Klaseman, Gatak, Sukoharjo. Peserta yang hadir merupakan perwakilan dari para pengurus dan anggota dari PRA terkait. Jumlah tersebut terbatas mengingat kondisi COVID-19 sehingga protokol kesehatan harus diterapkan. Materi yang disampaikan sesuai dengan obyek pengabdian ini yakni mengenai masalah hoaks di internet dan media sosial. Metode kegiatan di lapangan berupa presentasi melalui PPT, dilengkapi dengan contoh-contoh dan tayangan video. Selain itu, ada pula metode diskusi dengan mitra kegiatan untuk mengoptimalkan pemahaman atas materi yang disampaikan. Hasil yang dicapai dari kegiatan pengabdian kepada masyarakat ini adalah mitra kegiatan memiliki pengetahuan mengenai literasi media sehingga dapat bijaksana dan berhati-hati saat mengakses berbagai informasi di internet terutama media sosial.
\end{abstract}

Kata Kunci: hoaks, media sosial, pendidikan melek internet, aisyiyah

\section{PENDAHULUAN}

Sadar atau pun tidak, internet termasuk di sini media sosial sudah menjadi bagian yang tidak terpisahkan dari realitas kehidupan kita sehari-hari. Akses internet yang semakin mudah dan murah memberikan kontribusi tak terhingga bagi realitas virtual dari entitas atau pengguna (user) di ranah virtual. Seolah-olah bisa dikatakan entitas menjadi terikat dengan dunia virtual dan dunia offline-online tidak hanya terhubung secara paralel tetapi melebur dan menyatu (Boellstorff, Nardi, Pearce \& Taylor, 2012, dalam Nasrullah, 2017: 1). Internet telah menjadi bukti dan penciri utama bahwa peradaban manusia dewasa ini secara perlahan tapi pasti

$$
\text { Pendidikan }
$$


mengarah pada terbentuknya masyarakat informasi secara global. Masyarakat semakin bergantung pada internet dalam berbagai aktivitas kehidupan mereka sehari-hari.

Menurut seorang peneliti, saat ini "berbagai media sosial berbasis internet pun telah bermunculan mewarnai jagat baru komunikasi dan interaksi dalam sebuah desa global. Tak terhitung banyaknya hal positif yang muncul dari adanya media sosial. Media sosial mampu menjelma menjadi berbagai wadah dan artikulasi mulai dari hobi, bisnis, protes, identitas, politik, agama, gerakan sosial bahkan pemantik revolusi." (Alkhajar, 2019: xv-xvi). Segenap kepemilikan aneka media sosial itu pun telah menjadi semacam identitas kemodernan di jagat digital (Alkhajar, 2014; Alkhajar, 2019: xvi).

Internet sebagai media baru termasuk media sosial memang memberikan dan menyediakan banyak manfaat dan peluang untuk hal-hal baik (Alkhajar \& Luthfia, 2020). Namun, nyatanya ada saja pihak-pihak yang menyalahgunakannya untuk hal-hal buruk seperti hoaks, perundungan maupun ujaran kebencian.

Dengan kata lain, ibarat pisau bermata dua, internet termasuk media sosial, di satu sisi berisi dan mengajarkan berbagai hal-hal positif yang berguna bagi peradaban manusia. Namun di sisi lain, internet termasuk media sosial bermuatan dan menumpahkan berbagai konten negatif kepada publik luas hingga dampaknya sangat terasa dan tidak mudah diurai benang solusinya (Satyawan, 2019: xxi).

Itulah yang disebut kejahatan dunia maya (cyber crime) yang tipologinya sangat membentang luas secara online dari terorisme, radikalisme, hoaks, ujaran kebencian, perundungan, hingga plagiarisme. Inilah pula yang dilabeli era disrupsi di mana tidak sedikit orang yang terdampak secara negatif dari kehadiran teknologi internet dan media sosial (Satyawan, 2019: xxi). Selain itu, penggunaan internet yang tidak sehat dapat membawa kita pada direct violence dan socio cultural violence, meski tidak menampik bahwa di dalamnya terdapat kekerasan struktural yang ikut bermain (Vanel, 2019: xii).

Salah satu dari dampak negatif hadirnya internet dan terutama media sosial adalah munculnya dan berkembangnya informasi bohong atau hoaks (hoax) di ruang maya. Hoaks saat ini menjadi salah satu 'penyakit utama' dari efek dunia maya yang penetrasinya dari waktu ke waktu kian meningkat seiring peningkatan penggunaan internet dan media sosial itu sendiri.

Kecanggihan teknologi komunikasi dan penguasaan keterampilan teknis penggunaan teknologi terkait ternyata tidak berbanding lurus dengan kompetensi etis di kalangan sebagian netizen. Akhirnya yang terjadi, produksi hoaks makin menjamur baik netizen tersebut tahu atau paham atau sebaliknya tidak tahu atau tidak paham dalam memproduksi atau menyebarkannya (Wijaya \& Alkhajar, 2020: 232).

Menurut Kementerian Komunikasi dan Informatika RI, pada akhir 2016 terdapat sedikitnya 800 situs yang diduga menjadi produsen virus hoaks, berita palsu, dan ujaran kebencian. Tersebar melalui Facebook, Twitter, hingga grup-grup WhatsApp, virus itu langsung menyerang otak dan mengoyak nalar insani. Bila terpapar virus ini, orang akan mengalami skizofrenia informasi yang berujung lunturnya nurani, hilang kebijaksanaan akal dan keluhuran budi (Syaifuddin, 2017, dalam Wijaya, 2019: 61).

Ini disebabkan sifat dari media sosial yang memungkinkan akun anonim untuk berkontribusi, juga setiap orang tidak peduli latar belakangnya punya kesempatan yang sama untuk menulis. Tak heran, beberapa orang yang tidak bertanggungjawab menggunakan media sosial dalam konteks negatif, yaitu menyebarkan fitnah, hasut dan hoax (Ali, 2017: 92; Wijaya, 2019: 61).

Di sisi lain, kecenderungan penggunaan tema politik dan SARA sebagai komoditas utama produsen hoaks juga terlihat dari data Masyarakat Anti Fitnah Indonesia (Mafindo). Sepanjang Desember 2018, frekuensi hoaks terkait isu politik menempati peringkat pertama $(40,90 \%)$ sedangkan frekuensi hoaks SARA menempati posisi kedua (17\%). Tidak jarang kedua isu tersebut saling tumpang tindih, hoaks politik mengandung isu SARA dan sebaliknya isu SARA dikaitkan dengan isu politik (Nursahid et al., 2019: 3-4).

Fakta di atas semakin dipertegas dengan hasil survei Edelman Trust Barometer 2018 yang menyebut 7 dari 10 masyarakat dunia merasa khawatir jika berita palsu akan digunakan sebagai "senjata" [untuk menghantam pihak lain]. Di

$$
\text { Pendidikan }
$$


Indonesia sendiri, 76-80\% masyarakat khawatir akan pemanfaatan hoaks sebagai senjata untuk menciptakan ketidakstabilan dalam negeri. Kekhawatiran masyarakat ini tak lepas dari sebaran hoaks yang semakin cepat melalui media sosial (Gerintya, 2018).

Penyebarluasan berita hoaks, jika tidak segera ditangani, akan dapat menjadi bom waktu yang berbahaya bagi kelangsungan dan ketenteraman masyarakat. Dalam satu tahun terakhir, berbagai isu atau berita bohong diduga sengaja diciptakan dan makin intens disirkulasikan melalui media sosial, baik untuk kepentingan politis maupun motif ekonomi. Berita-berita bohong yang sulit dilacak kebenarannya dengan cepat menjadi viral di media sosial hingga memicu kegaduhan, keresahan, dan bahkan konflik manifes yang kontraproduktif. Dalam beberapa kasus, berita hoaks yang menjadi viral juga ditengarai telah mengancam stabilitas sosial politik dan merongrong wibawa pemerintah (Media Indonesia, 8 Januari 2017, dalam Ali, 2017: 93).

Terkait dengan latar belakang masalah itulah, maka diselenggarakan kegiatan workshop penyuluhan tentang literasi media ini. Kegiatan pengabdian tersebut dilaksanakan pada Sabtu, 22 Agustus 2020, di Desa Klaseman, Gatak, Sukoharjo yang dihadiri perwakilan para pengurus dan anggota Pimpinan Ranting Aisyiyah (PRA) Klaseman. Dipilihnya PRA Klaseman karena pertimbangan PRA Klaseman sebagai bagian dari Aisyiyah yang merupakan salah satu organisasi kemasyarakatan (Ormas) Islam perempuan besar di Indonesia yang memiliki anggota banyak sekitar 20 juta anggota. Pemberian literasi media mengenai hoaks mutlak dibutuhkan untuk memberikan pencerahan dan pendampingan kepada pengurus dan anggota Aisyiyah mengingat organisasi ini adalah bagian dari gerakan pencerahan dan pemberdayaan masyarakat di Indonesia.

Materi yang disampaikan sesuai dengan objek pengabdian ini yakni mengenai masalah hoaks di internet dan media sosial. Pemateri berasal dari tim dosen dari Sekolah Vokasi dan Fakultas Ilmu Sosial dan Ilmu Politik Universitas Sebelas Maret (UNS) Surakarta. Melalui kegiatan ini, diharapkan agar para peserta semakin bertambah wawasannya tentang hoaks serta lebih dapat berhati-hati dan bersikap bijaksana dalam mengakses internet dan media sosial.

\section{METODE}

Sebelum melaksanakan kegiatan, tim pengabdian kepada masyarakat melakukan komunikasi dan koordinasi secara intensif dengan mitra kegiatan. Di sisi lain, tim pengabdian juga memperhatikan nilai-nilai dan karakteristik unik yang dimiliki oleh desa yang menjadi lokasi kegiatan (Luthfia, 2013). Berbagai hal ini dilakukan untuk memastikan agar pelaksanaan kegiatan dapat berjalan dengan baik dan lancar sesuai dengan tujuan yang telah ditetapkan.

Kegiatan pengabdian kepada masyarakat ini berupa workshop literasi media tentang hoaks (hoax) di kalangan aktivis Pimpinan Ranting Aisyiyah (PRA) Klaseman, Gatak, Sukoharjo. Lokasinya berada di Desa Klaseman. Salah satu dari 14 desa yang terdapat di Kecamatan Gatak, Kabupaten Sukoharjo (BPS Kabupaten Sukoharjo, 2017).

Kegiatan ini pun dilaksanakan dengan memperhatikan protokol kesehatan yang ketat mengingat kondisi pandemi COVID-19. Dalam kondisi ini, semua pihak harus beradaptasi dan berdamai sebaik mungkin karena COVID-19 merupakan ancaman nyata bagi kesehatan setiap orang (Alkhajar \& Wijaya, 2020). Oleh karena itu, kehati-hatian dengan tetap menjaga protokol kesehatan merupakan hal penting yang harus dilakukan secara baik.

Adapun kegiatan workshop literasi media ini dilaksanakan selama sehari pada Sabtu, 22 Agustus 2020. Tim pengabdian menggunakan dua metode pendekatan, yakni: (1) Metode presentasi. Di sini pemateri menyampaikan materi-materi mengenai hoaks (hoax). Materi presentasi dalam bentuk slide PPT yang disertai dengan tampilan video untuk melengkapi materi yang disampaikan; (2) Metode diskusi. Di sini pemateri mengajak diskusi para peserta mengenai materi yang disampaikan melalui sesi tanya jawab.

Penggunaan dua metode ini dimaksudkan agar para peserta sebagai mitra kegiatan dapat semakin memahami atas materi-materi yang dipaparkan oleh tim pengabdian kepada masyarakat. Di sisi lain, hal tersebut juga dimaksudkan agar suasana kegiatan ini dapat menjadi lebih hidup dan dinamis sehingga dampak dan tujuan kegiatan pengabdian kepada masyarakat dapat tercapai di mana mitra kegiatan memiliki pengetahuan mengenai literasi media.

$$
\text { Pendidikan }
$$




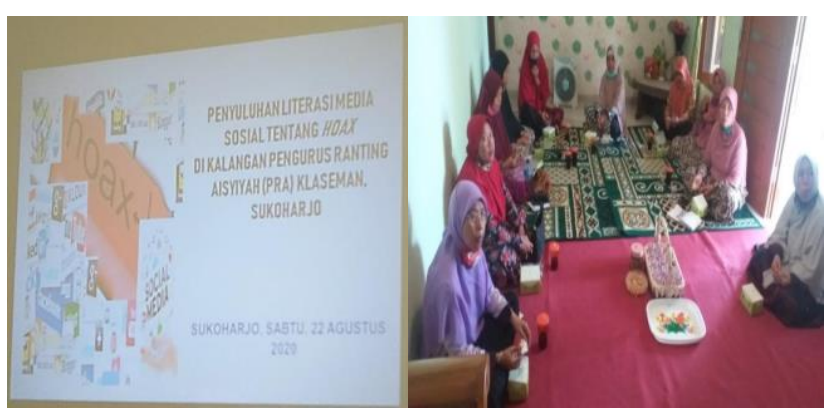

Gambar 1. Dokumentasi Kegiatan

Literasi Media tentang Hoaks di PRA

Klaseman, Gatak, Sukoharjo

Sumber: Dokumentasi Tim Pengabdian

\section{HASIL DAN PEMBAHASAN}

Pada kegiatan workshop literasi media tentang hoaks di PRA Klaseman, Gatak, Sukoharjo ini, terdapat sejumlah materi presentasi yang disampaikan antara lain data pengguna internet dan media sosial di dunia dan Indonesia, definisi hoaks, hasil riset tentang hoaks, penyebab terjadinya hoaks dan ciri-ciri hoaks beserta contoh-contohnya di internet dan media sosial.

\section{Definisi Hoaks}

Pada kegiatan ini tim pemateri menyampaikan mengenai sejumlah definisi mengenai hoaks dari sejumlah sumber literatur. Seperti yang dikemukakan organisasi literasi media, Indonesia Mendidik (2016), hoaks diartikan sebagai tindakan mengaburkan informasi yang sebenarnya, dengan cara membanjiri suatu media dengan pesan yang salah agar bisa menutupi pesan yang benar. Tujuan dari hoaks yang disengaja adalah membuat masyarakat merasa tidak aman, tidak nyaman, dan kebingungan. Dalam kebingungan, masyarakat akan mengambil keputusan yang lemah, tidak meyakinkan, dan bahkan salah (dalam Wijaya, 2019: 63).

Hoaks, menurut Pusat Studi Agama dan Demokrasi, Yayasan Paramadina dan Masyarakat Anti Fitnah Indonesia (Mafindo) diartikan sebagai informasi yang direkayasa, baik dengan cara memutarbalikkan fakta atau pun mengaburkan informasi, sehingga pesan yang benar tidak dapat diterima seseorang. Perkembangan penetrasi internet di Indonesia membuat platform media sosial seperti Facebook, Twitter, WhatsApp, Instagram, dan lainnya menjadi sarana efektif untuk mendistribusikan hoaks (Nursahid et al., 2019: 2).

Sementara hasil survei yang dilakukan Masyarakat Telematika Indonesia (Mastel) dan Tanpa Hoax Indonesia Sejahtera (THIS) tahun 2019 menyebutkan pandangan masyarakat Indonesia tentang hoaks yang menyebut hoaks sebagai berita bohong yang disengaja (88\%), berita yang menghasut $(49 \%)$, berita yang tidak akurat $(61 \%)$, berita ramalan/fiksi ilmiah $(15 \%)$, berita yang menyudutkan pemerintah (14\%), berita yang menjelekkan orang lain (31\%), berita yang tidak saya sukai (3\%), dan tidak tahu (1\%) (Mastel dan THIS, 2019).

\section{Penyebab Hoaks}

Tim pemateri pada kegiatan workshop ini juga menyampaikan materi mengenai beberapa sebab terjadinya hoaks di masyarakat, yaitu:

\subsection{Rendahnya Literasi Media}

Literasi media adalah kemampuan untuk mengakses, menganalisis, mengevaluasi dan mengirimkan pesan dalam format cetak dan non cetak (televisi, video, film, iklan dan internet) yang menyajikan berbagai hal (definition of supreme council) (Potter, 2005, dalam KPI Pusat Bidang Kelembagaan, 2012: 13).

Center for Media Literacy (Varis, 2000, dalam Wijaya, 2019: 439) merumuskan literasi media sebagai kemampuan berkomunikasi secara kompeten melalui semua media baik elektronik maupun cetak, di samping juga kemampuan mengakses, menganalisis dan mengevaluasi suara, kata-kata dan gambar yang berpengaruh yang membentuk kultur media massa kontemporer.

Literasi media ini sangat terkait dengan budaya membaca seseorang. Artinya seseorang yang gemar membaca, maka dirinya lebih bisa nalar dan bersikap kritis termasuk tatkala mengakses internet atau media sosial. Yang bersangkutan menjadi tidak mudah percaya begitu saja atas apa yang diaksesnya tanpa mengecek kebenaran informasi terkait. Dengan kata lain, seseorang tidak akan mudah terjebak dalam kondisi realitas semu (Alkhajar, 2007). Namun sepertinya, gemar membaca belum menjadi budaya Indonesia sehingga hoaks termasuk cukup banyak tersebar dalam belantara maya di Indonesia. Ini terlihat dari 
hasil survei studi Most Literate Nation In the World 2016 yang dilakukan Central Connecticut State University asal Amerika Serikat.

Hasil survei itu menyebut dari 61 negara, Indonesia menempati urutan ke-60 terkait dengan minat baca. Masyarakat Eropa atau Amerika khususnya anak-anak yang dalam setahun bisa membaca hingga $25-27 \%$ buku. Selain itu, juga ada Jepang yang minat bacanya bisa mencapai $15-18 \%$ buku per tahun. Sementara di Indonesia jumlahnya hanya mencapai $0,01 \%$ per tahun (Haryanto, 2017).

Riset serupa sebelumnya juga dilakukan oleh Programme for International Student Assessment (PISA) pada 2012 menunjukkan, Indonesia menduduki peringkat 60 dengan skor 396 dari total 65 peserta negara untuk kategori membaca. Hasil ukur membaca ini mencakup memahami, menggunakan, dan merefleksikan dalam bentuk tulisan. Skor rata-rata internasional yang ditetapkan oleh PISA sendiri adalah sebesar 500 (Firman, 2016).

\subsection{Faktor Psikologis}

Faktor psikologis ini berkaitan dengan kondisi kejiwaan dari netizen terkait hingga dirinya atau mereka memproduksi atau menyebarkan informasi hoaks disadari atau tidak disadari. Faktor psikologis ini misalnya terkait dengan sikap terburu-buru. Artinya netizen terburu-buru menyebarkan atau bahkan memproduksi informasi yang belum jelas kebenarannya. Bisa jadi yang bersangkutan menganggap informasi terkait adalah baik padahal termasuk hoaks. Hoaks ini banyak muncul pada jenis informasi kesehatan.

Faktor psikologis lainnya adalah fanatisme diri atau kelompok. Mereka ini bukan hanya menyebarkan hoaks namun malah memproduksi hoaks atas dasar sikap menganggap diri yang paling baik dan memandang salah atau rendah pihak lain terutama yang dipandang sebagai lawan. Fanatisme ini melahirkan ego diri dan sombong dalam bersikap. Faktor fanatisme ini banyak bermunculan pada jenis hoaks dengan konten sosial politik.

Apalagi saat hoaks berisi konten yang mendiskreditkan seorang tokoh atau kelompok yang berseberangan. Jika penyebaran berita palsu sudah sedemikian masif dan sistematis, muncullah situasi post-truth (pasca kebenaran). Post-truth adalah kondisi ketika fakta objektif atau kebenaran tak lagi relevan bagi pembaca, pendengar, atau pemirsa berita dalam membentuk opini publik. Mereka beralih sandaran kepada emosi dan keyakinan pribadi. Artinya, orang-orang dalam situasi posttruth memilih untuk menolak atau menerima kebenaran berita hanya berdasarkan selera pribadi (Hasan, 2019).

Faktor psikologis lainnya adalah perilaku iseng atau sekadar bermain-main dalam memproduksi atau menyebarkan hoaks. Yang bersangkutan sebenarnya tidak paham bahwa perilakunya adalah salah dan bahkan bisa berkonsekuensi hukum. Pelaku hoaks terkait melakukan itu bisa jadi karena ingin disebut "wah" oleh orang lain. Bisa jadi pula karena ingin uji coba mempraktikkan kemampuan teknologis dalam memproduksi atau membagi informasi di internet/media sosial tanpa sadar konten yang diproduksinya itu termasuk kategori hoaks.

\subsection{Kurang/Tidak Mengenali Ciri-Ciri Hoaks}

Diantara penyebab munculnya dan tersebarnya hoaks adalah para pelakunya belum/tidak mengenali ciri-ciri hoaks sehingga mereka ikut menyebarkan bahkan memproduksi hoaks terkait. Meski sebagian hoaks tidak mudah diidentifikasi, namun sebenarnya ada sebagian hoaks bisa dikenali ciri-cirinya dari tampilan fisiknya di internet atau media sosial seperti judul bombastis atau provokatif, konten berisi hasutan, foto/video editan dan lain-lain.

Untuk bisa mengenali ciri-ciri fisik hoaks, maka perlu belajar mengidentifikasi dari berbagai sumber atau contoh-contoh yang dikemukakan para ahlinya. Salah satu caranya dengan mengakses situs-situs anti hoaks yang ada di internet seperti turnbackhoax.id, cekfakta.com, dan situs-situs pendeteksi hoaks di portal-portal berita online dan platform media sosial. Selain itu, yang lebih penting adalah diperlukan kemampuan sikap kritis, skeptis dan hati-hati ketika menjumpai informasi di internet atau media sosial terutama yang tidak disebutkan atau tidak jelas sumbernya.

\subsection{Menurunnya Kepercayaan kepada Media Massa Arus Utama}

Merebaknya hoaks disebabkan oleh meningkat tajamnya ketidakpercayaan orang terhadap media mainstream. Media mainstream dianggap tidak objektif dalam menyampaikan berita. Media besar yang notabene milik pengusaha 
konglomerat diyakini oleh sebagian masyarakat sudah tidak lagi independen karena sarat dengan kepentingan bisnis dan politik. Masyarakat akhirnya beralih ke situs yang tidak jelas pengelola dan sumbernya, akibatnya situs hoax berkembang dengan pesat (MZR, 2010: 10).

Menurut data Dewan Pers tahun 2015, tercatat 43.300 media online. Namun, Dewan Pers hanya bisa memverifikasi sebanyak 168 media online. Selebihnya, Dewan Pers tidak mengetahuinya. Boleh jadi, media-media yang tidak terverifikasi itu termasuk media abal-abal yang berpotensi menyebarkan hoax. Penyebaran hoax juga sudah merembes ke dalam media-media mainstream, baik cetak, radio, televisi maupun new media (media yang berbasis internet) karena kurangnya verifikasi dan klarifikasi dalam proses jurnalistiknya (Wijaya, 2019).

\section{Beberapa Ciri Hoaks}

Pada kegiatan workshop literasi media tentang hoaks di PRA Klaseman, Gatak, Sukoharjo, para pemateri juga menyampaikan materi tentang sejumlah ciri-ciri hoaks. Perlu digarisbawahi di sini, tidak semua informasi dengan ciri-ciri yang disebutkan di sini mutlak sebagai hoaks, namun hanya sebagiannya saja masuk dalam kategori hoaks setelah dilakukan identifikasi lebih mendalam.

\subsection{Tanda Panah, Lingkaran, Huruf Besar, Warna Kontras}

Membuat tanda panah dan membuat lingkaran berwarna merah pada sebuah foto ternyata ampuh membuat masyarakat penasaran. Biasanya hal ini dilakukan untuk memancing orang lain untuk membaca atau menonton sebuah video yang sebetulnya tidak ada maknanya sama sekali. Selain tanda panah dan atau lingkaran, tanda lain yang sebagian terindikasi hoaks adalah judul dibuat dengan ukuran (font) besar dengan warna kontras menyolok, misalnya warna merah. Selain itu, juga bisa dengan tanda judul besar atau diberi tanda seru atau tanda-tanda lainnya disertai warna kontras.

Dengan tanda-tanda khusus pada judul yang tidak biasa atau menyolok maka diharapkan pembacanya akan tertarik dan terpengaruh, padahal informasinya hoaks atau tidak jelas. Seperti video hoaks yang sempat viral di YouTube tentang Kopi
Luwak White Coffee disebut bisa terbakar karena mengandung bahan berbahaya. Faktanya, video itu hanya hoaks semata di mana bisa terbakar karena berbentuk serbuk ringan, berpartikel halus dan mengandung minyak dan air dengan kadar yang rendah sebagaimana dikonfirmasi oleh Badan Pemeriksa Obat dan Makanan (BPOM) (Turnbackhoax.id, 2017; Wijaya, 2019: 110).

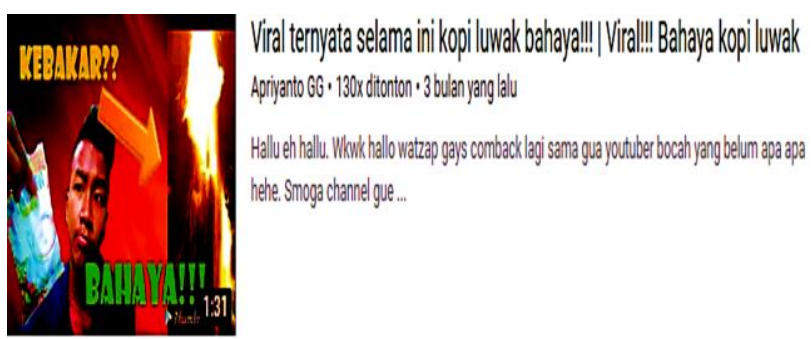

Gambar 2. Contoh Hoaks Soal Kopi Luwak Sumber: www.youtube.com (dalam Wijaya, 2019: 110)

\subsection{Menggunakan Judul yang Spektakuler}

Untuk membuat penasaran, biasanya berita bohong menggunakan judul yang tidak masuk diakal dan membuat penasaran. Tidak jarang mereka juga menambahkan kata-kata seperti "mencengangkan", "baru terjadi", "menakjubkan" dan lain-lain.

Dengan menggunakan trik ini, pembaca akan sangat penasaran dan meningkatkan rasio klik dari artikel yang mereka share dan untuk memancing pengunjung agar lebih banyak yang masuk ke dalam suatu situs atau website tertentu. Seperti pada video hoaks yang sempat viral di YouTube bahwa Pimpinan Pusat (PP) Muhammadiyah mendukung pasangan Prabowo Subianto-Sandiaga Uno (Prabowo-Sandi) pada Pilpres 2019. Padahal sebagaimana diketahui bersama, PP Muhammadiyah menyatakan netral dalam Pilpres 2019 dan berusaha menjaga jarak dengan politik praktis sebagaimana sikap politik selama ini sejak berdirinya tahun 1912 (Wijaya, 2019: 111). 


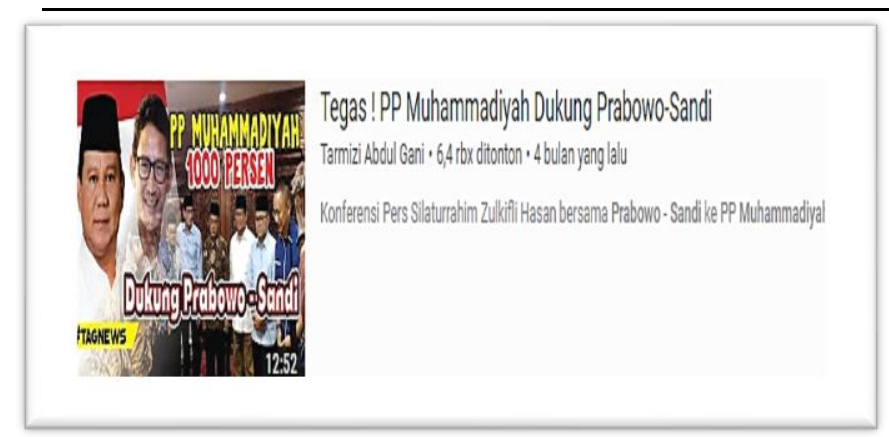

Gambar 3. Contoh Hoaks tentang PP Muhammadiyah dan Pilpres 2019 Sumber: www.youtube.com (dalam Wijaya, 2019)

\subsection{Isi Informasi Membuat Kecemasan/ Kebencian/Permusuhan (Fear Arousing)}

Masyarakat yang terpapar hoaks biasanya akan terpancing perdebatan. Jika sudah berdebat, mereka akan saling benci dan bermusuhan. Berita palsu diarahkan agar timbul rasa tidak nyaman setelah membacanya seperti pembaca merasa cemas, marah, atau tidak suka terhadap suatu peristiwa, tokoh, dan atau kelompok (Komisi Komsos KWI, 2018: 78). Seperti pada kasus hoaks tentang penculikan anak di India. Hoaks itu tersebar melalui grup WhatsApp (WA) bahkan hingga terjadi main hakim sendiri dan jatuhnya korban jiwa (Wijaya, 2019: 117).

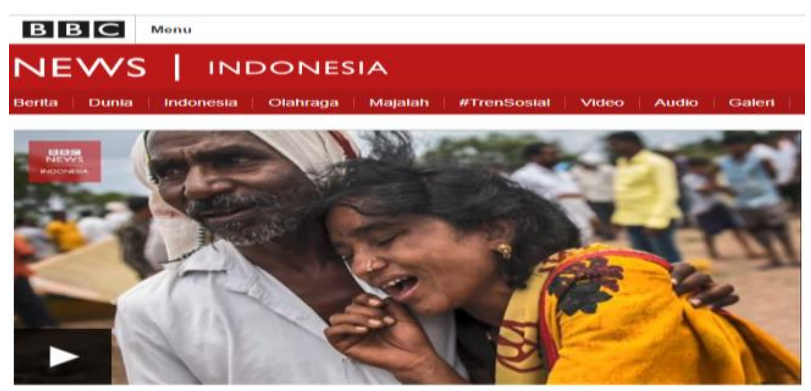

Hoaks penculik anak di India, dua pemuda meregang nyawa di tangan warga

Gambar 4. Contoh Hoaks tentang

Penculikan Anak di India

Sumber: www.bbc.com (dalam Wijaya, 2019)

\subsection{Informasi Tidak Berimbang/Cenderung Menyudutkan Pihak Tertentu (Onesided)}

Dalam pandangan penulis, ciri berita/informasi hoaks adalah berita yang memberatkan satu sisi/pihak baik sisi baiknya atau sisi buruknya secara penuh atau sebagian besar, padahal setelah dicek secara valid (fakta), informasi itu palsu (hoaks). Tentu saja berita/informasi ini merugikan nama baik pihak-pihak tertentu yang merasa nama baiknya dipublikasi secara tidak berimbang.

Hoaks mengunggulkan sebuah pihak dan menjatuhkan pihak lain. Subyektivitas yang dimasukkan di dalam tulisan untuk menyebut halhal baik dan argumen dapat menjadi indikator bahwa apa yang kita baca tergolong sebagai hoaks (Komisi Komsos KWI, 2018: 79). Sebagai contoh, hoaks tentang Presiden Jokowi disebut terkait Partai Komunis Indonesia (PKI) yang tersebar di media sosial. Info itu tentu jelas hoaks semata karena faktanya Presiden Jokowi sama sekali tidak ada kaitannya dengan PKI (Wijaya, 2019: 119).

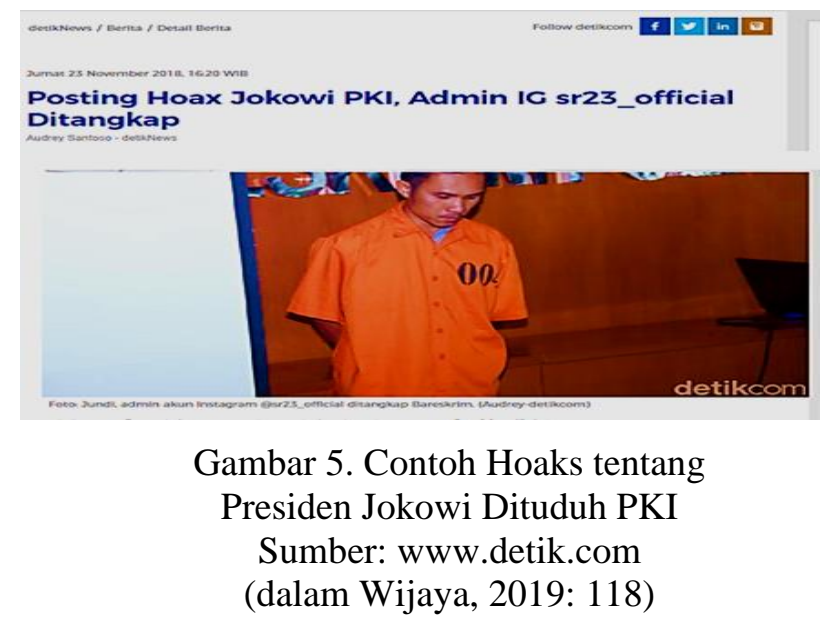

\subsection{Bermuatan Fanatisme Atas Nama Ideologi (Plain Folks)}

Ciri berita/informasi yang terindikasi sebagai hoaks, menurut pandangan penulis, adalah isinya terkesan kuat menampilkan luapan ideologi tertentu yang dipedomani oleh pembuatnya. Misalnya ideologi radikal/ekstremis/teroris, isinya berupa pengagungan cara pandangannya dengan merendahkan pandangan lain yang tidak sama dengan dirinya seperti penggunaan idiom-idiom "taghut", "kafir", "neraka”, "jihad" maupun "perang suci" yang digunakan secara serampangan tanpa mendedah maksud sebenarnya.

Hal ini juga berlaku pada jenis ideologi lain seperti ideologi politik ekstrem yang tak jarang diwarnai dengan balutan ideologi keagamaan yang radikal. Sebagai misal, hoaks foto bergambar anak- 
anak korban tewas dibunuh Presiden Basyar Al Assad dalam konflik di Suriah yang tersebar di media sosial. Namun faktanya foto tersebut hoaks karena aslinya foto-foto tersebut adalah foto anakanak korban kebiadaban tentara Israel di Gaza, Palestina pada Januari 2009 (Wijaya, 2019: 120).

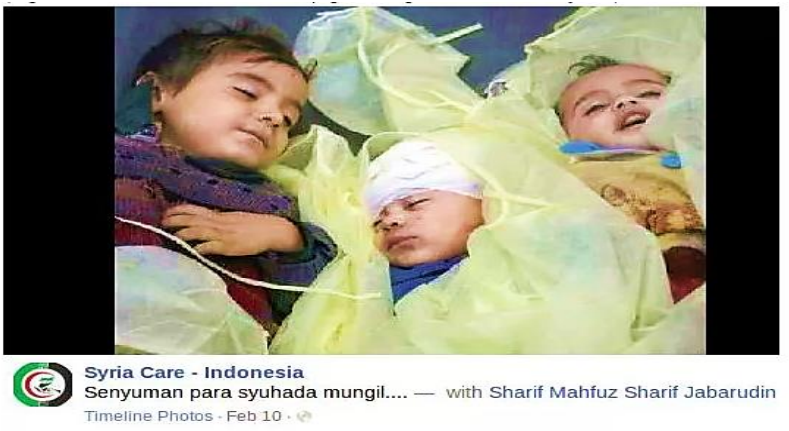

Gambar 6. Contoh Hoaks tentang Korban Konflik di Suriah Sumber: https://www.kaskus.co.id (dalam Wijaya, 2019: 120)

\subsection{Judul dan Pengantarnya Provokatif}

Banyak judul yang provokatif memiliki indikasi kuat termasuk berita/informasi hoaks. Misalnya menggunakan kata-kata bernada "kasar" atau berlebihan. Tidak jarang, judul provokatif dan bombastis ini ditulis dengan huruf tebal, ukuran besar dengan warna kontras tajam, misalnya warna merah menyala. Menurut Komisi Komunikasi Sosial Konferensi Waligereja Indonesia (KWI) (2018: 81-82), penulisnya sengaja memilih judul dan lead yang sensasional, bombastis, dan provokatif agar pembaca segera tertarik untuk membacanya. Teknik ini juga dipakai untuk menarik perhatian calon pembaca meskipun isi hoaks tersebut tidak sesuai dengan judul (clickbait).

Seperti di media sosial tersebar foto atau video yang menyebut mantan Paus Vatikan, Paus Benedictus menjadi mualaf dan sedang menunaikan ibadah haji. Namun bisa dipastikan ini merupakan kabar hoaks. Pasalnya, potongan video tersebut merupakan Pangeran Khalid Al-Faisal yang sedang melakukan Jumroh pada hari Rabu, 22 Agustus lalu di Mina, Arab Saudi (Turnbackhoax.id, 2018; Wijaya, 2019: 122).

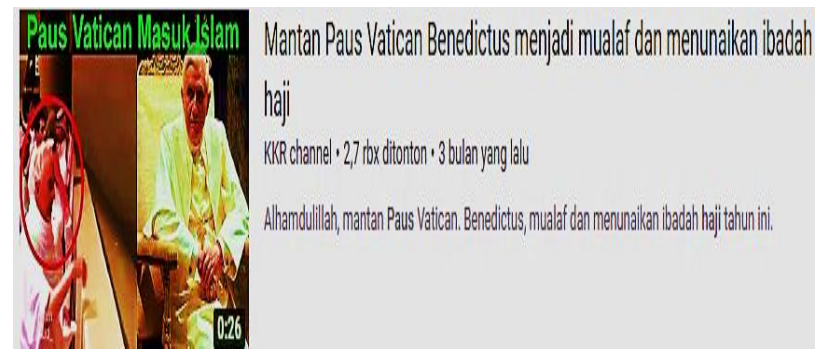

Gambar 7. Contoh Hoaks tentang Paus Benedictus Masuk Islam

Sumber: www.youtube.com (dalam Wijaya, 2019)

\subsection{Mencatut Nama Tokoh Tertentu (Transfer Device)}

Menurut pandangan penulis, jenis berita/informasi hoaks adalah dengan cara mencatut nama pihak tertentu (orang/lembaga) yang dinilai berpengaruh sehingga seolah-olah itu resmi berasal dari pihak tersebut. Faktanya, pihak tersebut tidak merasa mempublikasikan informasi/berita hoaks terkait, bahkan nama baiknya dirugikan atas publikasi tersebut. Pihak yang memposting berita/informasi hoaks itu memiliki tujuan bermacam-macam seperti menjatuhkan nama baiknya, menguatkan kepentingannya dan membuat kebingungan publik.

Di antara informasi hoaks dengan cara mencatut nama pihak tertentu adalah meme di media sosial yang menampilkan gambar pendiri Persyarikatan Muhammadiyah, KH. Ahmad Dahlan. Hoaks tersebut dianggap merugikan nama baik Muhammadiyah karena Muhammadiyah dikira tidak menyukai rezim penguasa karena terkait terjadinya bencana alam. Faktanya, itu hanya hoaks semata oleh pihak-pihak yang tidak bertanggung jawab dengan cara memanipulasi nama pendiri Muhammadiyah, KH. Ahmad Dahlan (Wijaya, 2019: 126) 


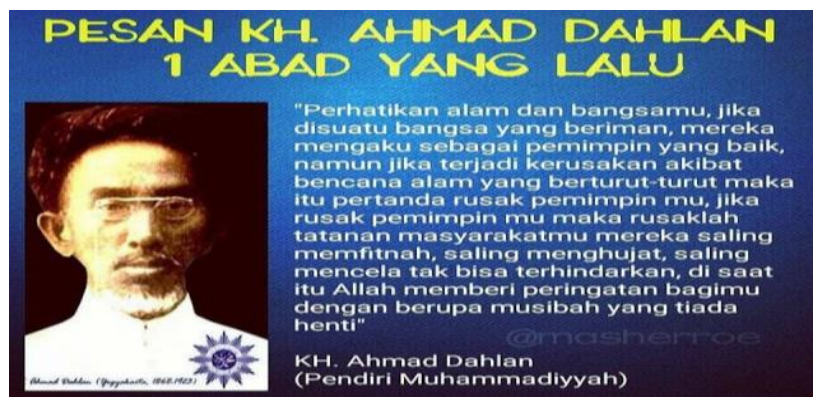

Contoh 8. Hoaks tentang

KH Ahmad Dahlan dan Bencana Alam Sumber: https://twitter.com (dalam Wijaya, 2019)

\subsection{Memberi Julukan Tertentu (Name Calling/Labelling)}

Kemudian jenis informasi/berita yang dicirikan kategori hoaks adalah vulgar memberi julukan (calling/labelling) kepada pihak lain. Biasanya julukan yang diberikan itu bersifat peyoratif (buruk) atau sarkas (kasar) sehingga tentunya merugikan nama baiknya. Ada unsur generalisasi memutlakkan hal buruk tertentu padahal belum tentu pihak yang dijuluki itu seperti apa yang dituduhkan. Hal ini disebabkan karena adanya unsur kepentingan tertentu, misalnya dendam, kepentingan politik dan ekonomi.

Penggunaan nama julukan, istilah, sebutan, yang merujuk kepada orang atau kelompok yang dibahas pada hoaks tersebut. Pemberian julukan ini ditujukan untuk membangun atau impresi tertentu sesuai keinginan produsen hoaks, dan menghindari jerat hukum terkait pencemaran nama baik (bila menggunakan nama langsung) (Komisi Komsos KWI, 2018: 81).

Misalnya, ada informasi di media sosial tentang video Gus Dur (KH. Abdurrahman Wahid, Presiden RI tahun1999-2001, mantan Ketua Umum Nahdlatul Ulama (NU) sebagai seorang murtad. Hal ini karena di video tersebut tampak Gus Dur bersama umat Kristiani dalam acara do'a bersama di Persidangan Doa Kebangsaan di Senayan Jakarta, 12-16 Mei 2003. Faktanya, video itu adalah hoaks. Gus Dur membantah telah dibaptis menjadi non muslim dengan mengatakan kalau dirinya dibaptis, pastinya dirinya tidak ke acara itu. Gus Dur diundang dalam acara itu dalam kapasitasnya untuk memberikan ceramah kebangsaan (Wijaya, 2019: 132).

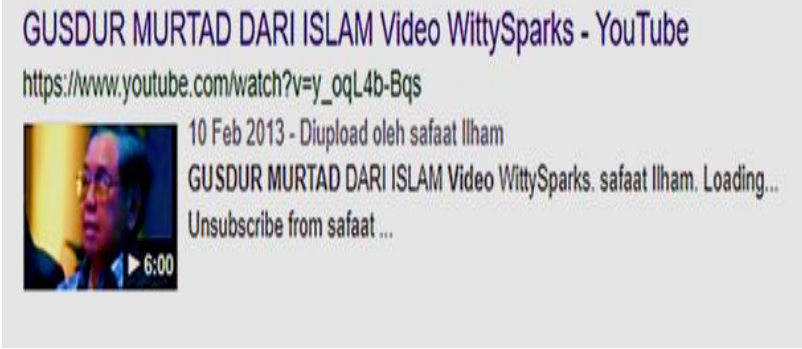

Gambar 9. Contoh Hoaks tentang Gusdur Disebut Murtad dari Islam

Sumber: www.youtube.com (dalam Wijaya, 2019: 132)

\section{9. "Memelintir" Pernyataan Pihak Tertentu}

Sebagian model hoaks yang muncul adalah dalam bentuk "pemelintiran" pernyataan pihakpihak tertentu seperti pernyataan atau kata-katanya sehingga mengakibatkan terjadi bias makna atau melenceng dari maksud sebenarnya. Selain viral di media sosial, "pemelintiran" pernyataan itu menjadi semakin ramai di publik karena "digoreng"di sana sini sehingga bisa menjadi bola liar dan tentu merugikan pihak yang membuat pernyataan yang "dipelintir" itu. Mengutip istilah dari Komisi Komsos Konferensi Waligereja Indonesia (KWI) (2018: 83), pemotongan fakta dan data dapat mengubah maksud pesan asli sehingga dipakai untuk kepentingan produsen hoaks.

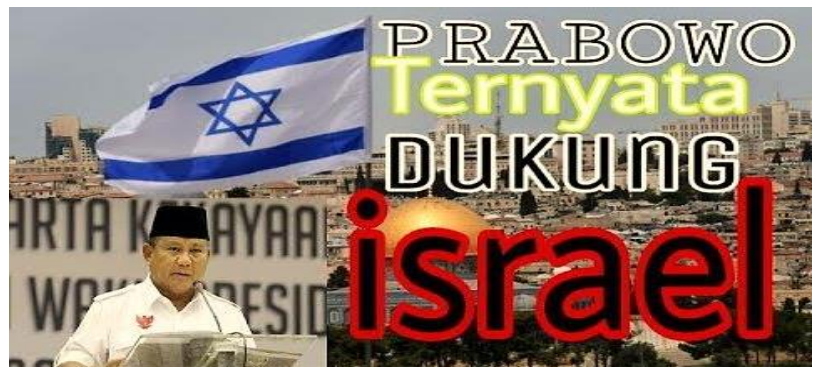

Gambar 10. Contoh Hoaks tentang Prabowo Dukung Israel

Sumber: https://stafabandz.web.id (dalam Wijaya, 2019: 137)

Sebagai contoh di media sosial viral beredar informasi yangmenyebutkan salah seorang Capres 2019, Prabowo Subianto mendukungIsrael. Hal ini karena komentarnya tentang rencana pemindahan Kedutaan Besar Australia ke Yerusalem sebagai

$$
\text { Pendidikan }
$$


urusan Australia. Sebagai negara independen berdaulat, Prabowo menghormati rencana Australia itu. Namun komentarnya itu dipelintir di media sosial menjadi seakan-akan Prabowo pro Israel. Prabowo sendiri membantah bahwa itu adalah hoaks dan menegaskan dirinya, juga bangsa Indonesia tetap sebagai pendukung Palestina (Wijaya, 2019: 137).

\subsection{Manipulasi Foto/Gambar/Video dan Caption (Keterangan Penjelasnya)}

Ada lagi jenis hoaks yang viral di media sosial yakni jenis hoaks yang berisi foto atau video yang diedit sedemikian rupa sehingga seolah-olah asli. Dengan kecanggihan teknologi, editing itu tampak seperti sebenarnya meskipun jika dicek benar-benar ternyata editing itu manipulatif. Sebagian foto atau video yang digunakan biasanya sudah lama dan berasal dari kejadian di lokasi lain. Untuk memperkuat editingnya itu, keterangan atas foto atau video yang dimaksud juga ikut dimanipulasi (misalnya keterangan atas foto atau caption). Tujuan dari postingan ini untuk menjatuhkan pihak tertentu atau hanya sekadar iseng.

Foto-foto yang digunakan biasanya sudah lama dan berasal dari kejadian di tempat lain dan keterangannya juga dimanipulasi. Pelaku juga dapat mengubah latar dan foto sebuah peristiwa dengan mengandalkan kecanggihan piranti pengolah gambar dan keterampilannya (Komisi Komsos KWI, 2018: 83). Sebagai contoh beredar foto di media sosial mantan Gubernur DKI Jakarta, Basuki Tjahaja Punama (Ahok) melakukan salam komando dengan Habib Rizieq. Faktanya, foto itu tidak pernah ada dan hanya rekayasa/editan semata oleh pihak tertentu.

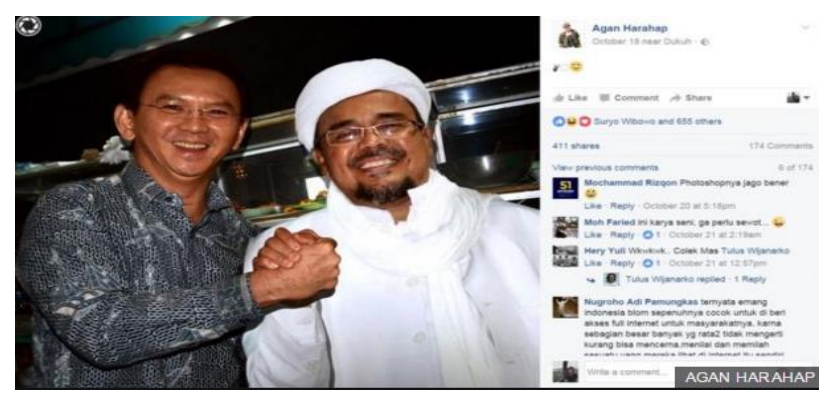

Gambar 11. Contoh Hoaks tentang

\author{
Ahok dan Habib Rizieq \\ Sumber: https://www.bbc.com (dalam Wijaya, \\ 2019: 116)
}

\subsection{Jika Sudah Ada Klarifikasi, Maka Itu Hoaks}

Satu lagi ciri informasi atau berita hoaks adalah jika telah ada klarifikasi resmi dari pihak terkait atau ahli yang diakui kepakarannya mengenai hal yang menjadi hoaks itu. Begitu berita/informasi hoaks itu muncul atau tersebar, maka dengan segera ada klarifikasi atas hoaks terkait tentang bagaimana isi sebenarnya. Klarifikasi dilakukan oleh pihak terkait yakni pelurusan yang dilakukan langsung oleh orang/instansi yang namanya disebutkan dalam berita hoaks itu. Sementara klarifikasi oleh pakar/ahli yakni pelurusan dilakukan oleh ahli/pakar tertentu yang diakui kepakarannya mengenai hal yang menjadi hoaks itu dan dinyatakan bahwa berita itu memang hoaks.

Sebagai contoh foto hoaks adalah beredarnya di media sosial sebuah foto hitam-putih yang menggambarkan sosok pemimpin Partai Komunis Indonesia (PKI), Dipa Nusantara Aidit, sedang berpidato di sebuah acara partai. Di foto tersebut ada foto seseorang berdiri di depan mimbar Aidit yang disebut sebagai Presiden Joko Widodo. Informasi itu jelas adalah hoaks karena foto itu dibuat ketika Pemilu tahun 1955 oleh fotografer jurnalistik Majalah Life asal Amerika, Howard Sochurek.

Presiden Jokowi sendiri tegas membantah itu hoaks karena dirinya baru lahir tahun 1961, sedang foto itu dibuat tahun 1955, sehingga tidak mungkin ada seseorang berumur 6 tahun sudah menjadi anggota partai politik (Wijaya, 2019: 144). Sejarawan LIPI, Dr. Asvi Warman Adam juga mengklarifikasi dengan memastikan bahwa pria yang berdiri di depan mimbar Aidit dipastikan bukan Joko Widodo (Jokowi). Dikatakannya, Jokowi lahir 1961, sedang Aidit ditembak 1965 atau sebelumnya (Wijaya, 2019: 145). 
Gambar 12. Contoh Hoaks tentang Jokowi Ikut Kampanye PKI

Sumber: https://nasional.kompas.com (dalam Wijaya, 2019: 144)

\subsection{Jika Telah Diberitakan Media Massa Arus Utama (Mainstream)}

Penciri lain dikatakan sebuah berita/informasi itu masuk kategori hoaks adalah adanya pemberitaan di media massa arus utama (mainstream). Jika media massa arus utama (resmi yang telah terverifikasi sebagai badan hukum dan lembaga pemverifikasi seperti Dewan Pers) telah memberitakan dan menyebut informasi terkait sebagai hoaks, maka bisa dipastikan bahwa informasi itu adalah hoaks. Seperti di media sosial sempat beredar foto-foto yang disebut sebagai pesawat Lion Air JT 610 yang jatuh. Faktanya, foto ini adalah bangkai pesawat Lion Air JT-904 yang mengalami musibah di Bandar Udara I Gusti Ngurah Rai, Bali, pada 13 April 2013 (Wijaya, 2019: 146).

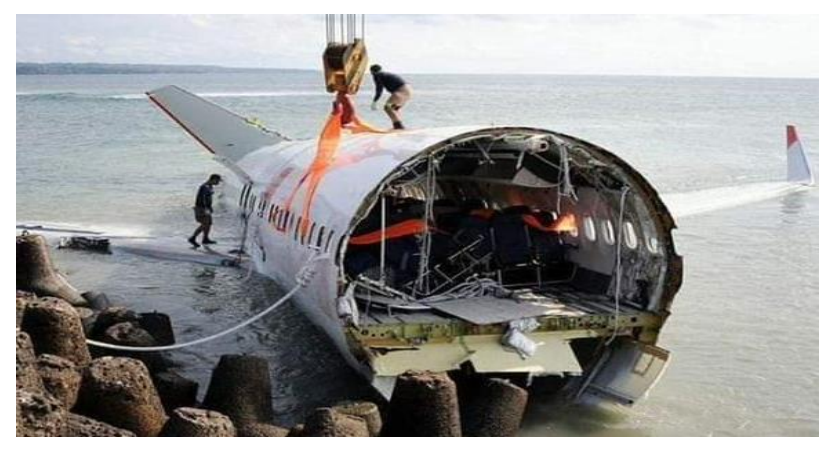

Gambar 13. Contoh Foto Hoaks

Lion Air JT 610 Jatuh

Sumber: https://news.detik.com (dalam Wijaya, 2019: 146).

Berbagai paparan materi mengenai literasi media di atas telah memberikan pengetahuan kepada mitra kegiatan berkaitan dengan hoaks dan berbagai hal yang terkait dengan hoaks yang mana kerap muncul di internet maupun media sosial. Dampak yang diharapkan setelah adanya kegiatan pengabdian kepada masyarakat ini adalah mitra kegiatan semakin memiliki kehati-hatian dan bijak dalam merespons dan mengakses berbagai informasi yang beredar secara deras di internet maupun media sosial.

Di sisi lain, setelah kegiatan ini mitra kegiatan juga diharapkan dapat menjadi penangkal hoaks dengan tidak menyebarkan informasi yang belum jelas kebenarannya sehingga mitra kegiatan dapat memainkan peran penting untuk aktif bersama-sama dalam menjaga kesehatan informasi publik (Wijaya \& Alkhajar, 2020).

\section{KESIMPULAN}

Secara keseluruhan pelaksanaan kegiatan pengabdian kepada masyarakat ini berjalan dengan baik dan lancar di mana mitra kegiatan mengikuti setiap paparan materi dengan antusiasme yang besar. Dari pembahasan di atas, maka kesimpulan yang dapat ditarik adalah hoaks merupakan informasi yang tidak benar dan menyesatkan bagi publik luas.

Oleh karena itu, hoaks sangat berbahaya karena memiliki potensi destruktif yang besar. Tak heran, hoaks bahkan dapat menimbulkan pertentangan dan konflik sosial. Hoaks muncul dan tersebar setidaknya disebabkan empat faktor yaitu rendahnya literasi media, pengaruh psikologis, kurang atau tidak mengetahui ciri-ciri fisik hoaks dan menurunnya tingkat kepercayaan kepada media besar (arus utama).

Adapun beberapa ciri dari hoaks diantaranya adalah: (1) Menggunakan tanda panah, lingkaran, judul besar, warna kontras; (2) Menggunakan judul berita yang spektakuler; (3) Isi informasi membuat kecemasan/kebencian/ permusuhan (fear arousing); (4) Informasi tidak berimbang/cenderung menyudutkan pihak tertentu (onesided); (5) Bermuatan fanatisme atas nama ideologi (plain folks); (6) Judul dan pengantarnya provokatif; (7) Mencatut nama tokoh tertentu (transfer device); (8) Memberi julukan tertentu (name calling/labelling); (9) "Memelintir" pernyataan pihak tertentu; (10) Manipulasi foto/ gambar/video dan caption; (11) Jika sudah ada 
klarifikasi, maka itu hoaks; (12) Jika telah diberitakan media massa arus utama (mainstream).

\section{REFERENSI}

Ali, M. (2017). Antara Komunikasi, Budaya dan Hoax. In A. Wahyudin \& M. Sunuantari (Eds.), Melawan Hoax di Media Sosial dan Media Massa (pp. 89-107). Yogyakarta: Trustmedia Publishing.

Alkhajar, E. N. S. (2007). Hiperealitas dalam Kehidupan Nyata. Kompas, 31 Desember.

Alkhajar, E. N. S. (2014). Media, Masyarakat dan Realitas Sosial. Surakarta: Sebelas Maret University Press.

Alkhajar, E. N. S. (2019). Literasi Media Baru, Ketidakberpikiran dan Esensi Kemanusiaan di Era Digital. In S. H. B. Wijaya, Seri Literasi Media: Dari Hoax Hingga Hacking (pp. xv-xix). Yogyakarta: Buku Litera. https://doi.org/10.31219/osf.io/eu78j

Alkhajar, E. N. S., \& Luthfia, A. R. (2020). Diseminasi dan Publikasi Karya Tulis Berbasis Media Baru. Bakti Cendana, 3(2), 62-67. https://doi.org/10.32938/bc.v3i2.614

Alkhajar, E. N. S., \& Wijaya, S. H. B. (Eds.). (2020). Dinamika Komunikasi dalam Pandemi COVID-19. Yogyakarta: KBM Indonesia. https://doi.org/10.31219/osf.io/4zk85

BPS Kabupaten Sukoharjo. (2017). Kecamatan Gatak dalam Angka 2017. Sukoharjo: BPS Kabupaten Sukoharjo.

Firman, T. (2016, August 18). Literasi Indonesia yang Belum Merdeka. Diakses September 18, 2020, dari https://tirto.id/literasi indonesia-yangbelum-merdeka-bBJS.

Gerintya, S. (2018, May 17). Hoaks dan Bahaya Rendahnya Kepercayaan kepada Media. Diakses September 18, 2020, dari https://tirto.id/hoaks-dan-bahaya-rendahnya-

kepercayaan-kepada-media-cKAx.

Haryanto, A. (2017, August 11). Najwa Paparkan Data Soal Rendahnya Minat Baca Indonesia. Diakses September 18, 2020, dari https://tirto.id/najwa-paparkan-data-soalrendahnya-
minat-baca-indonesia-cupM.

Hasan, A. M. (2019, January 14). Masalah Orangtua: Gemar Membagi Hoaks di Medsos dan WhatsApp. Diakses September 18, 2020, dari https://tirto.id/masalah-orangtua-gemar-membagihoaks-di-medsos-dan-whatsapp.

Komisi Penyiaran Indonesia Pusat Bidang Kelembagaan. (2012). Meretas Jalan Sosialisasi Literasi Media Di Indonesia: Materi Pelatihan Untuk Pelatih Kegiatan Literasi Media KPI Pusat. Jakarta: Komisi Penyiaran Indonesia.

Luthfia, A. R. (2013). Menilik Urgensi Desa di Era Otonomi Daerah. Journal of Rural and Development, 4(2), 135-143.

Mastel \& THIS. (2018). Hasil Survey Mastel Tentang Wabah Hoax Nasional. Jakarta: Mastel \& THIS.

MZR. (2017). Indonesia dan Hoax yang Menggurita. UI Lib Berkala, 3(1), 10-11.

Nasrullah, R. (2017). Etnografi Virtual: Riset Komunikasi, Budaya dan Sosioteknologi di Internet. Bandung: Simbiosa Rekatama Media.

Nursahid, A., Kartika, D. Y., Rafsadie, I., Khairil, M., Astuti, S. I., Mulyartono, S. (2019). Melawan Hasutan Kebencian. Jakarta: PUSAD Yayasan Paramadina \& Mafindo.

Satyawan, A. (2019). Meliterasi Publik di Tengah Paradoksial Informasi. In S. H. B. Wijaya, Seri Literasi Media: Dari Hoax Hingga Hacking (pp. xxi-xxii). Yogyakarta: Buku Litera.

Tim Komisi Komsos Konferensi Waligereja Indonesia (KWI). 2018. Pedoman Penggunaan Media Sosial. Jakarta: Komisi Komsos KWI.

Turnbackhoax.id. (2017, August 27). Penjelasan BPOM Terkait Hoax serta Isu Mengenai Makanan. Diakses September 18, 2020, dari https://turnbackhoax.id/2017/08/27/edukasipenjelas an-bpom-terkait-hoax-serta-isu-mengenaimakanan/.

Turnbackhoax.id. (2018, August 26). Hoaks Video Yang Sebut Paus Benekditus Pergi Haji. Diakses September 18, 2020, dari https://kalbar.turnbackhoax.id/index.php/2018/08/2 6/hoaksvideo-yang-sebut-paus-benekditus-pergi-

Pendidikan 764 
haji/.

Vanel, Z. (2019). Peran Teknologi Pintar dalam Pembangunan Perdamaian. In S. H. B. Wijaya, Seri Literasi Media: Dari Hoax Hingga Hacking (pp. xi-xiii). Yogyakarta: Buku Litera.

Wijaya, S. H. B. (2019). Seri Literasi Media: Dari Hoax hingga Hacking. Buku Litera: Yogyakarta.

Wijaya, S. H. B., \& Alkhajar, E. N. S. (2020). Memotret Pandemi: Hoaks Covid-19 dan Paradoks Kemanusiaan. In F. Junaedi (Ed.), Krisis Komunikasi dalam Pandemi Covid-19 (pp. 229233). Yogyakarta: Buku Litera. https://doi.org/10.31219/osf.io/rn3vh 